\title{
International Public Sector Accounting Standards (IPSAS) Adoption and Implementation in Nigerian Public Sector
}

\author{
Ademola Abimbola O. ${ }^{1}$, Ben-Caleb E. ${ }^{1}$, Madugba Joseph U. ${ }^{1}$, Adegboyegun Adekunle E. ${ }^{1}$ \& Eluyela Damilola F. ${ }^{1}$ \\ ${ }^{1}$ Department of Accounting \& Finance, Landmark University, Omu-Aran, Kwara State, Nigeria \\ Correspondence: Ademola Abimbola.O, Department of Accounting \& Finance, Landmark University, Omu-Aran, \\ Kwara State, Nigeria.
}

Received: July 31, 2019

Accepted: October 30, 2019

Online Published: December 16, 2019

doi:10.5430/ijfr.v11n1p434

URL: https://doi.org/10.5430/ijfr.v11n1p434

\begin{abstract}
This study evaluated the relationship between IPSAS adoption and financial reporting quality in South West, Nigeria. Specifically, it analysed the effect of IPSAS adoption on credibility and comparability of financial statements. Additionally; salient factors influencing IPSAS implementation were investigated. Primary data collected from one hundred and eighty accountants in South West Nigeria were analysed using tabulation, graphs, factor analysis, and Goodman and Kruskal's gamma statistics.

The empirical results indicated that IPSAS adoption exerted significant and positive relationships with financial reporting quality, credibility and comparability of financial statements. Decisively, discoveries from this study reflect that implementation cost, staff training, technological factor, IPSAS knowledge and awareness and availability of expertise significantly affect IPSAS implementation. However, findings further revealed that IPSAS implementation is not significantly influenced by institutional commitment, cultural, sociological, legal, political and environmental factors. Based on these findings, the authors recommend that considerable amount of money should be set aside for full adoption and implementation of IPSAS in Nigeria.
\end{abstract}

Keywords: financial reporting quality, comparability, credibility, adoption, public sector, Nigeria

JEL Classification: M40, M41, M48

\section{Introduction}

Globalization has enhanced inter-connection of economies and cultures among different nations over the globe. Specifically, it depicts high intensity of cross-border trade, expanded financial and foreign direct investment flows, accompanied by quick liberalization and advances in information technologies (Ajayi, 2001; Danas, 2001). Globalization engenders a historical revolution and inevitably affects the accounting sector. As a result, reconciliation of accounting systems becomes successful under globalization. It is therefore obvious that to function optimally in the world economy and to be recognized internationally; no nation can perform independently in its financial reporting standards.

Hence, the need for harmonized accounting standards that would remain acceptable and comprehensible to users across the globe. International Public Sector Accounting Standards (IPSAS) is presently the focus of worldwide transformation in Public sector accounting in reaction to quest for more prominent coordination and comparability of financial statements through global best practices. IPSAS according to IFAC, 2017 are highly rated worldwide accrual-based accounting standards which creates qualitative and accurate financial information that enhances accountability and equally builds trust with citizens. IPSAS are the public sector equivalent of International Financial Reporting Standards (IFRS). IFRS gives a straightforward and precise financial overview of listed companies globally, using accruals accounting in contrast to cash accounting. The transition to IPSAS has the capacity to alter financial reporting practice in the public sector as IFRS have achieved with listed companies in private sectors

IPSAS ensures high standards which accelerates the provision of credible financial statements. This enhances functional performance and efficient distribution of resources. Ademola, Adegoke \& Oyeleye (2017) noted that IPSAS adoption ensures excellent financial operations by increasing the level of accountability and transparency. Also, it reveals financial misappropriations quickly within the public sector however big such institution is. This is possible because IPSAS provides a self-regulated internal control system. The adoption of IPSAS is spreading fast 
globally. For instance, Australia and New Zealand changed from IFRS to IPSAS standards for government owned entities. South-East Asia and South America's endorsement for IPSAS triggered other developing countries.

Moreover, Africa is at the cutting edge of IPSAS adoption as many countries are proposing to embrace the standards as a component of financial management reform programme in Africa, countries that have adopted IPSAS include Rwanda, Tanzania, Uganda, Zambia, Algeria, Ghana, Nigeria, South Africa, Liberia, Morocco and Mauritania. In line with globalization trend across the globe, Nigeria, the giant of Africa also approved the adoption of IPSAS in 2010.This is done with the hope of curbing the growing corruption that has beleaguered public sector organizations and to improve good governance.

However, as IPSAS is being adopted by many countries, implementation of IPSAS in the Organization for Economic Cooperation Development (OECD) country is still very low (IFAC, 2017). Nigeria is still far behind in its implementation. The three tiers of the Nigerian government were to implement cash IPSAS by 2014 and accrual IPSASs by 2016 but they all failed to meet the targeted dates. The incessant failure to implement IPSAS in Nigeria is ironic because the same country has enforced and successfully implemented the IFRS for its private sector organizations without delay but IPSAS implementation has been lingering for years. Several researchers revealed that issues such as high cost of IPSAS implementation and inadequate skilled personnel among others are responsible for the failed implementation (Atuilik, Adafula \&Asare, 2016; Omolehinwa, \& Naiyeju, 2015; Tikk, 2010 \& Tickell, 2010).

However, several seminars and workshops have been conducted to create public awareness and train practitioners so as to ensure a smooth passage to the IPSAS regime, despite all these efforts, IPSAS implementation continues to suffer serious setback. Unfortunately, continuous delay in the implementation of IPSAS counteracts the actualization of the benefits associated with it such as economic leverage and good relationship with sovereign nations because the country cannot operate in isolation in the World. Therefore, it becomes imperative to examine critically the factors influencing IPSAS implementation in Nigeria.

\subsection{Statement of the Problem}

As numerous as the benefits of IPSAS adoption and implementation are to a country, many countries are yet to adopt IPSAS, while many of those that adopted IPSAS are yet to implement it. Though Nigeria adopted IPSAS in 2010, the rate of IPSAS implementation is very slow. This indicates non conformity with IFAC public sector reform strategy. This problem of slow implementation can cause the nation to be less attractive to foreign direct investment. Thus, the delay in IPSAS implementation poses a serious problem to the country at large.

Moreover, many researchers have divergent opinions concerning IPSAS adoption and implementation in Nigeria; some believe it is in the right direction. For instance, Acho (2014) found out that IPSAS implementation aids the reconciliation of financial processes and consistency of public sector financial reports. Ijeoma \& Oghoghomeh (2014) buttressed this assertion by reporting that implementation of IPSAS makes financial reports in Nigeria and around the world easily comparable. However, some researchers exercise caution on the implementation of IPSAS. Chan (2005) argued that IPSAS contribution to institutional capacity building is negligible in less developed countries. Omolehinwa \&Naiyeju (2015) further reported that the implementation of IPSAS could be very expensive. Arising from the inconsistencies in these reports and the problems stated above, this research provides answers to the following questions:

- What are the salient factors affecting IPSAS implementation in Nigeria?

- Is there any association between IPSAS adoption and financial reporting quality in Nigeria?

- Does any relationship exist between IPSAS adoption and credibility of financial statements?

- What is the relationship between IPSAS adoption, comparability and international best practice in Nigeria?

1.2 Hypotheses of the Study

- There is no association between IPSAS adoption and financial reporting quality in Nigeria.

- There is no relationship between credibility of financial statements and IPSAS adoption.

- IPSAS adoption have no significant relationship with comparability and international best practice among public sector organisation in Nigeria 


\section{Literature Review}

\subsection{Conceptual Issues}

\subsubsection{Conceptual Framework of IPSAS}

IPSAS are financial reporting standards issued for public sector entities. They originated from International Public Sector Accounting Standards Board (IPSASB). They are the public sector equivalent of International Financial Reporting Standards (IFRS) which are applicable only to private sector companies. IPSAS deal specifically with financial reporting matters that were not attended to in IFRS. In January 2016, thirty-nine (39) IPSAS were issued by IPASB out of which thirty-eight (38) were strictly based on accrual basis of financial reporting. The IPSASB endorsed accrual basis and regard cash basis as inadequate in meeting the demands of financial report users. IPSASB (2015) explains that the standards apply to public sector entities and are useful for the preparation of financial statements. The objective of IPSAS is to assist government officials in making choice decisions for public governance to be conducted transparently and creditably.

\subsubsection{IPSAS Adoption and Quality of Financial Reporting}

Financial Reporting Quality is the extent to which financial reports represent the financial position of an organization truthfully (Tang, Chen \& Zhijun, 2008). Its main objective is to provide choice information on reporting entities for good economic decision (IASB, 2010). Qualitative financial reports have a strong and positive influence on capital providers and other stakeholders when making economic decisions that may increase the efficiency of capital markets (IASB, 2008)

IPSAS was principally developed to guide government owned entities in preparing qualitative financial reports and proper implementation of IPSAS helps to boost the quality and reliability of reporting systems within government institutions (Brown, 2013). Opaniyi (2016) found out that IPSAS standard are essential in developing qualitative financial reports. Moreover, IFAC also recommended accrual basis of financial reporting to ensure consistency, comparability and enhance credibility of financial reports (Udeh \& Sopekan, 2015).

\subsubsection{IPSAS Adoption and Comparability of Financial Information}

Comparability entails uniformity in the usage of similar accounting policies and procedures from one period to another in and outside an organization (IASB, 2010). It expresses the desire for government owned entities to have consistent financial reports that correspond to others (Okoh \& Ohwoyibo (2010). In government owned entities, accountant-general of the federation are supposed to put together and present to the concerned authorities and interested parties, financial reports free from inaccuracies and comparable with related public entities (Kayode, 2014). For comparability of financial information to rise to a meaningful height in government owned entities, IPSASB (2012) admonished countries to adopt IPSAS. Atu, Atu, and Okoye (2013) opined that IPSAS adoption facilitates coordination of financial reports ultimately leading to comparability of financial information around the world.

Relatedly, Oduware (2012) and Bellanca and Vandernoot (2014) found that IPSAS adoption made comparability of financial information easier by presenting financial information promptly and transparently. Furthermore, Christiaens, Vanhee, Manes-Rossi, and Aversano (2013) ascertained that IPSAS adoption improves comparability of financial information, consolidates financial statements and brings about international best practices in government owned entities worldwide. Additionally, if government owned entities adopt IPSAS, there are high prospects of receiving international supports.

\subsubsection{IPSAS Adoption and Credibility of Financial Statements}

Credibility is the quality of being believable or trustworthy. Mhaka (2014), Ofoegbu (2014) and Chan (2008) revealed that IPSAS adoption enhances credibility of financial statements. This is possible because IPSAS based financial statements comply with the principle of double entry system which is not applicable to cash basis of accounting. Thus, IPSAS adopt international best practices in the preparation and presentation of financial statements taking into consideration all the accounting concepts and conventions.Mhaka (2014) further confirmed that IPSAS adoption opens room for increased global and universal perceived credibility of financial information which undoubtedly accelerates accountability. Bellanca \&Vandernoot (2014) buttressed this assertion by reporting that IPSAS adoption reveals substantial facts and figures in financial transactions of government.

Furthermore, it builds confidence in citizens, partners both within and overseas, thereby encouraging investors and increasing the country's access to international support. IPSAS positions government accounting with best accounting practices by using credible accounting standards; improves internal controls and clarity with reference to 
assets and liabilities; promotes public private partnerships due to better accountability and transparency of the public sector; makes available comprehensive information about costs for results oriented management; and promotes cross border investments thereby enhancing the flow of foreign direct investments (Atuilik, 2017; Atuilik, Adufula \& Asare, 2016).

\subsection{Theoretical Framework}

This study made use of stakeholder's theory. It is established on the premise that "values are inevitably and precisely important components of businesses. It requires managers to express clearly the value they produce, and what connects its stakeholders so as to achieve their objectives (Freeman, Wicks \&Parmar 2004). Financial statements are examined thoroughly by stakeholders in order to determine its efficiency according to this theory. The users of the IPSAS in the government owned entities suggest that its execution is crucial for performance evaluation, accountability and efficiency. The relevance of this theory as it pertains to government owned entities is that several stakeholders have a fixed and absolute interest in a financially feasible government.

\subsection{Empirical Review on IPSAS Adoption and Implementation}

IPSAS adoption and implementation have numerous advantages. For instance experiences from countries such as Abu Dhabi, Albania, Australia, Azerbaijan, Bangladesh, Brazil, Canada, Cayman Islands, Cyprus, Costa Rica, East Timor, Solomon Islands, Tanzania, Uruguay and Uganda which adopted and implemented the standard witnessed numerous benefits such as enhanced financial transparency and credibility; improvement in assets management and qualitative financial reporting formaking good decisions. Moreover, it boosts international relations with ease of access to international loans and grants (Malahleha, 2013).

IPSAS adoption is regarded as a major public accountability reform which enhances transparency and accountability (Anderson, 2009).Furthermore, Bergmann (2011) asserted that IPSAS implementation enhances accountability and oversight control over public finances; improves transparency in government accounting and financial reporting thereby positively influencing government's cost of financing; better recognition of risks and opportunities which in turn reduces the likelihood of unexpected surprises and reduces default risks. Mhaka (2014) revealed that the challenges facing cash-based accounting would be overcome by IPSAS adoption. Moreover, Atuilik (2016) and Ademola et al., (2017) reported significant and negative association between IPSAS adoption and the level of perceived corruption. This suggests that IPSAS adoption by governments is related closely to reduction in the perception of corruption. Tickell (2010) also observed that the quest for increased accountability necessitated many countries to adopt IPSAS. Chan (2003) asserted that IPSAS impacts significantly on governments accounting policies that are not IPSAS based.

Ijeoma \&Oghoghomeh (2014) found that IPSAS implementation have tremendous benefits like increasing level of accountability, providing information for decision making thus helping to enhance theservice delivery quality thereby strengthening good governance and relations between the government and the governed. IPSAS focuses on specific issues relating to government in financial reporting, providing adequate guidance for all types of government transactions or interventions. Additionally, Udeh \& Sopekan (2015) found out that IPSAS adoption improves financial reporting quality of government owned entities in Nigeria.

Moreover, Alan and Susan (2007) postulated that IPSAS adoption guides the preparation and presentation of financial reports to ensure that they are presentable to global users. Based on this premise, Adama\& Ahmed (2014) affirmed that IPSAS is an acceptable development that enhances global best practices, create room for accountability and increase credibility rating in Nigeria.

\section{Methodology}

This study focused on Ministries, Departments and Agencies (MDAs) in South West Nigeria especially Oyo, Osun, Ogun and Kwara States. All the members of Institute of Chartered Accountants of Nigeria (ICAN) and Association of National Accountants of Nigeria (ANAN) in the selected areas constitute the population of the study. This research focused on State governments because government has a high stake in achieving IPSAS adoption and implementation framework in the area of legislation, enforcement and monitoring.

A total of one hundred and eighty (180) respondents comprising one hundred and twenty (120) Public Sector Accountants and sixty (60) Auditors in the MDAs of the selected states with at least five (5) years of work experience were purposively selected for the study. These are foremost practitioners in charge of IPSAS adoption, thus representing the characteristics of Public sector in South West, Nigeria. Data were generated from primary sources through well- structured questionnaires. Meanwhile data were analysed using tabulation, graphs, factor analysis and Goodman and Kruskal's gamma statistics. 
Table 1. Reliability test

\begin{tabular}{ll}
\hline Reliability Test & \\
\hline Cronbach's Alpha & Number of Items \\
\hline $\mathbf{0 . 7 9}$ & 18 \\
\hline
\end{tabular}

Source: Authors computation, 2019

After considerable efforts were channeled into drafting questions, the instrument was further subjected to Cronbach Alpha to ensure reliability of the instrument. The reliability test shows 0.79 representing $79 \%$ reliability. This indicates that all the variables have high internal consistency rate and thus instrument is considered reliable.

\section{Empirical Results andDiscussion}

\subsection{IPSAS Adoption and the Quality of Financial Reporting in Nigeria's Public Sector}

From the data presented in Table 2, it can be seen that 75 percent of the respondents consented that IPSAS adoption improves overall quality of financial reports. Results indicated that respondents agreed with items 2, 3, 4, 5 and 6 . This showed that IPSAS based standards are objective, free from bias, detailed, comprehensive and integrated. It is also easy to prepare and understand thereby communicating value relevance to beneficiaries. All these are strong indications that IPSAS adoption improves financial reporting quality.

As indicated in Table 3, result from Goodman and Krukal's Gamma Analysis showed that financial reporting quality have very strong positive relationship $(G=0.728)$ with IPSAS adoption. The extent of the relationship is 0.728 . The hypothesis tested showed $\mathrm{P}<0.005$ suggesting rejection of the null hypothesis. Therefore, the alternate hypothesis which stated that there is an association between IPSAS adoption and financial reporting quality in Nigeria is accepted. The implication is that if IPSAS is adopted by any country, then financial reporting quality is guaranteed because it assists users to prepare highly rated qualitative financial reports. Moreover, qualitative financial reports increase the efficiency of capital markets by influencing capital providers and other interested parties when making economic decisions (IASB, 2008). This finding is in line with Brown (2013) that IPSAS was principally developed to guide government owned entities in preparing qualitative financial reports which helps to boost the quality and reliability of reporting systems within government institution. Opaniyi (2016) also asserted that IPSAS standards are essential in developing qualitative financial reports. Ozugbo (2009) buttressed this assertion by reporting that IPSAS adoption eliminates partial disclosure of financial information as it is presently the case in most government entities. This finding is also in consonance with the submission of Ball \&Plugrath (2012) that proper application of IPSAS standards produces qualitative financial reports for enhanced comparability. Moreover, Ijeoma (2014) also posited that IPSAS adoption enables financial reports to be reliable and consistent.

Table 2. IPSAS adoption and quality of financial reporting

\begin{tabular}{|c|c|c|c|c|c|c|}
\hline $\mathbf{S} / \mathbf{N}$ & $\begin{array}{l}\text { IPSAS Adoption and Quality of Financial } \\
\text { Reporting }\end{array}$ & $\begin{array}{l}\text { SA } \\
\text { F(\%) }\end{array}$ & $\begin{array}{l}\mathbf{A} \\
\mathbf{F}(\%)\end{array}$ & $\begin{array}{l}\mathbf{U}(\%) \\
\end{array}$ & D & $\begin{array}{l}\text { SD } \\
\text { F }(\%)\end{array}$ \\
\hline 1. & $\begin{array}{l}\text { Introduction of IPSAS improves theoverall } \\
\text { financial reports quality }\end{array}$ & $60(33.33)$ & $75(41.67)$ & $18(10.00)$ & $15(8.33)$ & $12(6.67)$ \\
\hline 2. & $\begin{array}{l}\text { Financial statements that are IPSAS based } \\
\text { are objective and free from bias. }\end{array}$ & $52(28.89)$ & $72(40.00)$ & $30(16.67)$ & $18(10.00)$ & $8(4.44)$ \\
\hline 3. & $\begin{array}{l}\text { IPSAS adoption makes the financial reports } \\
\text { to be more comprehensive and integrated }\end{array}$ & $41(22.78)$ & $75(41.67)$ & $30(16.67)$ & $22(12.22)$ & $12(6.66)$ \\
\hline 4. & $\begin{array}{l}\text { IPSAS adoption is essential in building } \\
\text { detailed, relevant and qualitative financial } \\
\text { reports }\end{array}$ & $50(27.78)$ & $70(38.89)$ & $25(13.89)$ & $25(13.89)$ & $10(5.55)$ \\
\hline 5. & $\begin{array}{l}\text { IPSAS based financial reports are easily } \\
\text { understandable, lacks technical jargons and } \\
\text { complexity }\end{array}$ & $22(12.22)$ & $52(28.89)$ & $48(26.67)$ & $40(22.22)$ & $18(10.00)$ \\
\hline 6. & $\begin{array}{l}\text { IPSAS adoption will communicate } \\
\text { valuerelevance to beneficiaries of financial } \\
\text { reporting. }\end{array}$ & $50(27.78)$ & 68 (37.78) & $30(16.67)$ & $20(11.11)$ & $12(6.66)$ \\
\hline
\end{tabular}

Source: Authors computation, 2019 
Table 3. Goodman and Kruskal's gamma test to examine the association between IPSAS adoption and financial reporting quality

\begin{tabular}{|c|c|c|c|c|c|}
\hline \multicolumn{6}{|l|}{ Symmetric Measures } \\
\hline & & Value & Asymp. Std. Error ${ }^{a}$ & Approx. $\mathrm{T}^{\mathrm{b}}$ & Approx. Sig. \\
\hline Ordinal by Ordinal & Gamma & .728 & .078 & 7.038 & .000 \\
\hline $\mathrm{N}$ of Valid Cases & & 180 & & & \\
\hline
\end{tabular}

Source: Authors computation, 2019

\subsection{IPSAS Adoption and Credibility of Financial Statements.}

Findings as displayed in Fig 3 revealed that 120 respondents (more than 65 percent) agreed that IPSAS based financial statements are more credible than traditional cash basis of accounting. This may be due to the fact that IPSAS makes use of all accounting concepts and conventions, adopt double entry principles in the preparation of accounts and exposes fraudulent transactions and reports. Thus, making financial statements credible to various users.

In addition to this, Table 4 showed the nexus between IPSAS adoption and credibility of financial statements using Goodman and Krukal's Gamma Analysis. The result revealed that positive and significant association exist between IPSAS adoption and credibility of financial statements $(\mathrm{G}=0.736, \mathrm{p}<.005)$. This suggests that IPSAS based financial statements are convincing and can be relied upon. It builds confidence in citizens, partners both within and overseas, thereby encouraging investors and increasing the country's access to international support. Low level of trust and confidence in government has the effect of reducing both local and foreign direct investments in the economy which in turn reduces opportunities for accelerated economic growth and development. Where quality reporting framework is missing, government financial transactions will be plagued with under development and economic deprivation. The above findings are in line with the submission of (Chan, 2008; Mhaka, 2014; Ofoegbu, 2014) that IPSAS adoption in public corporations enhances clarity and trustworthiness of financial statements. Also, Bellanca \&Vandernoot (2013) confirmed that IPSAS adoption reveals substantial facts and figures in financial transactions of government owned entities.

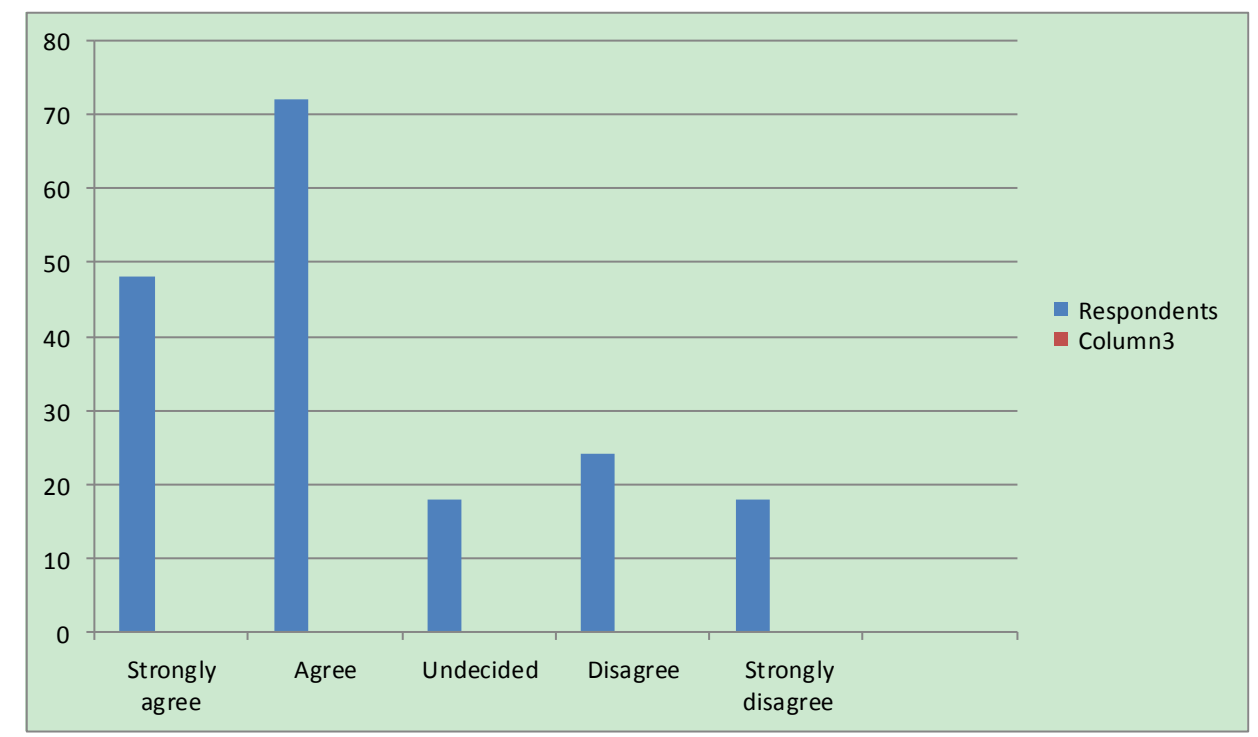

Figure 1. IPSAS adoption and credibility of financial statements

Source: Field Survey, 2019 
Table 4. Goodman and Kruskal's gamma test to determine the relationship between IPSAS adoption and credibility of financial statements

\begin{tabular}{lllllll}
\hline Symmetric Measures & Value & $\begin{array}{l}\text { Asymp. } \\
\text { Error }^{\mathrm{a}}\end{array}$ & Std. & Approx. T & Approx. Sig. \\
\hline $\begin{array}{l}\text { Ordinal } \\
\text { Ordinal }\end{array}$ & by & Gamma & .736 & .096 & 4.219 & .000 \\
\hline $\mathbf{N}$ of Valid Cases & 180 & & & \\
\hline
\end{tabular}

Source: Author's computation, 2019

\subsection{IPSAS Adoption and Comparability of Financial Information}

Findings revealed that more than 60 percent of the respondents admitted that IPSAS adoption stimulates comparability of financial information in government owned entities (Table 4). Also, majority affirmed that comparable information provided by IPSAS adoption assists both local and international stakeholders in evaluating how well their resources have been employed. Furthermore, 65 percent of the respondents agreed that collaboration between Private and government owned entities may be achieved with both utilizing identical accounting standards (IPSAS and IFRS) and this would definitely improve public-private partnership.

Moreover, result from Goodman and Krukal's gamma analysis in Table 6 showed that comparability of financial statements has a very strong positive relationship $(G=0.733)$ with IPSAS adoption. The extent of the relationship is 0.733 . The hypothesis tested showed $\mathrm{P}<0.005$ suggesting rejection of the null hypothesis. Therefore, the alternate hypothesis which states that there is an association between IPSAS adoption and comparability of financial statements in Nigeria is accepted. This implies that financial statements generated using IPSAS can be easily compared with others anywhere in the world.

In consonance with this finding, Oduware (2012) and Bellanca \& Vandernoot (2014) found that IPSAS adoption have made comparability of financial information easier by presenting financial information promptly and transparently. Furthermore, Christiaens et al., (2013) ascertained that IPSAS adoption improves comparability of financial information, consolidates financial statements and brings about international best practices in government owned entities worldwide. This finding also confirmed the assertion that harmonised and comparable information is provided when a country adopts and comply with IPSAS provisions (Babatunde, 2017; IFAC, 2017). It also tallies with the submission of Ball \&Plugrath (2012) that proper application of IPSAS standards produces qualitative financial reports for enhanced comparability.

Table 5. IPSAS adoption and comparability of financial reports

\begin{tabular}{|c|c|c|c|c|c|c|}
\hline $\mathbf{S} / \mathbf{N}$ & $\begin{array}{l}\text { IPSAS Adoption and Comparability of } \\
\text { Financial Reports }\end{array}$ & $\begin{array}{l}\text { SA } \\
\text { F }(\%)\end{array}$ & $\begin{array}{l}\text { A } \\
\text { F }(\%)\end{array}$ & $\begin{array}{l}\mathrm{U} \\
\mathrm{F}(\%)\end{array}$ & $\begin{array}{l}\text { D } \\
\text { F }(\%)\end{array}$ & $\begin{array}{l}\text { SD } \\
\text { F }(\%)\end{array}$ \\
\hline 1. & $\begin{array}{l}\text { IPSAS adoption ensures increased } \\
\text { comparability, strong internal controls and } \\
\text { better financial management }\end{array}$ & $35(22.50)$ & $72(40.00)$ & $25(15.00)$ & $30(12.50)$ & $18(10.00)$ \\
\hline 2. & $\begin{array}{l}\text { IPSAS adoption ensures comparability of } \\
\text { financial information among public entities in } \\
\text { Nigerian Public Sector }\end{array}$ & $42(23.33)$ & $75(41.67)$ & $30(16.67)$ & $23(12.78)$ & $10(5.55)$ \\
\hline 3 & $\begin{array}{l}\text { Adoption of IPSAS ensures that government's } \\
\text { financial transactions are reported holistically }\end{array}$ & $48(26.67)$ & $71(39.44)$ & $28(15.56)$ & $25(13,89)$ & $8(4.44)$ \\
\hline 4. & $\begin{array}{l}\text { IPSAS adoption ensures that financial reports } \\
\text { are comparable globally. }\end{array}$ & $35(19.44)$ & $77(42.78)$ & $32(17.78)$ & $24(13.33)$ & $12(6.67)$ \\
\hline 5. & $\begin{array}{l}\text { IPSAS adoption assists the stakeholders in } \\
\text { evaluating that their resources have been } \\
\text { optimally employed. }\end{array}$ & $38(21.11)$ & $78(43.33)$ & $28(15.56)$ & $20(11.11)$ & $16(8.89)$ \\
\hline
\end{tabular}




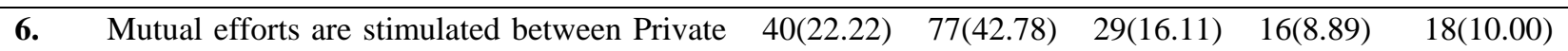
and government owned entities with bothutilising identical accounting standards (IPSAS and IFRS).

Source: Author's computation, 2019

Table 6. Goodman and Kruskal's gamma test to determine the relationship between IPSAS adoption and comparability of financial statements

\begin{tabular}{llllll}
\hline Symmetric Measures & & & & \\
\hline & & Value & Asymp. Std. Error & Approx. T $^{\mathrm{b}}$ & Approx. Sig. \\
\hline Ordinal by Ordinal & Gamma & .733 & .086 & 5.441 & .000 \\
\hline N of Valid Cases & & 180 & & & \\
\hline
\end{tabular}

Source: Author's computation, 2019

\subsection{Factors Affecting IPSAS Implementation in Nigeria}

The factors affecting IPSAS implementation was analysed using Factor Analysis. Kaiser-Meyer-Olkin (KMO) was employed to measure the sampling adequacy. Table 7 showed that the KMO measure is 0.761 ; this implied that the data are adequate and suitable. Also, the significance value $\mathrm{p}<0.005$ for Sphericity test indicate that the variables are correlated which makes it germane to factor analysis. Thus, the values of the test are considered significant.

Moreover, Table 8 showed the principal component analysis consisting of the extracted factors, eigen values, percent of variance, cumulative variance of the factors and previous factors. Five factors (Implementation cost, Staff training, Technological factor, IPSAS Knowledge and Awareness and Availability of Expertise) accounts for 19.363\%, $14.257 \%, 11.797 \%, 10.684 \%$ and $9.168 \%$ of the variance respectively. However, the remaining factors like institutional commitment, cultural, sociological, legal, political and environmental factors were insignificant. Furthermore, the scree plot as shown in Fig 2 depicts the graph of the eigen values against all the factors. The graph determines the factors to retain. The utmost concern is where the curve begins to flatten. This is between factors 4 and 5. It shows that the first five factors having eigen values of 1 and above could only be retained.

Implementation costs which accounts for $19.363 \%$ of the variance ranked highest. IPSAS implementation is viewed as an expensive project which governments are either unable or unwilling to undertake especially with so many developmental needs seeking for attention. It involves several costs like staff training costs, hardware and software acquisition costs among others. This makes IPSAS implementation pretty difficult for countries. Delloite \& Touch (2011) buttressed this assertion that for IPSAS to be implemented, costs such as research, training, technology, and consultancy should be well catered for. Moreover, Mohammed \& Allawi (2014) confirmed that costs significantly affect IPSAS implementation. In the same vein, Ouda (2004) reported that many countries are unable to implement IPSAS because of inadequate finances on their part.

Staff training ranked next with variance of $14.257 \%$. This showed that staff training is imperative for successful IPSAS implementation and that without training and re-training of accounting professionals, IPSAS implementation may not be sustainable and may yield little or no efforts. This finding is in line with Tickell (2010) who emphasized the need for thorough training, re-training, and retention of accounting staff in public sector institutions. Furthermore, Prewitt (2013) opined that staff training cost is a major barrier to IPSAS implementation in developing countries. Iyoha \& Jimoh (2011) also reported that education and training of accountants affects IPSAS implementation significantly.

In addition to these, Technological factor with variance of $11.797 \%$ serves as one of the major factors affecting IPSAS implementation.With IPSAS implementation, the management information system of the government will be improved in line with the financial data requirements of IPSAS standards (Price Waterhouse Coopers, 2011). Moreover, management information system currently in use will be evaluated for adequacy. All these measures definitely require considerable costs, efforts time and recruitment of information technology staff. To further buttress this finding, Ouda (2004) opined that computerized information system is very essential to IPSAS implementation. 
IPSAS Knowledge and Awareness is another factor that accounts for $10.684 \%$ of the variance. IPSAS implementation cannot be effective without public awareness. The citizenry at large should be carried along with various phases of IPSAS implementation. Street (2004) affirmed that nations with low level of public consciousness fail in IPSAS implementation. Therefore, series of seminars and workshops to raise public awareness, educate and train various practitioners should be organised to guarantee smooth transition to IPSAS.

Additionally, availability of Expertise accounts for $9.168 \%$ of variance. Without requisite expertise, IPSAS implementation would be an illusion. Reports from United Nations Conference on Trade and Development (UNCTAD, 2008) affirmed that inadequate trained accounting personnel makes IPSAS implementation complex. Also in Kenya, Hamisi (2012) found out that availability of expertise is of great significance to IPSAS implementation; however, unavailability of expertise and insufficient skills may lead to delays in IPSAS implementation.

Table 7. KMO and Barlett'stest

\begin{tabular}{lll}
\hline \multicolumn{2}{l}{ KMO and Bartlett's Test } & \\
\hline \multicolumn{2}{l}{ Kaiser-Meyer- Olkin Measure of Sampling Adequacy. } & .761 \\
\hline Bartlett's Test of Sphericity & Approx. Chi-Square & 145.251 \\
\cline { 2 - 3 } & Df & 55 \\
\cline { 2 - 3 } & Sig. & .000 \\
\hline
\end{tabular}

Table 8. Extraction method: principal component analysis

\begin{tabular}{|c|c|c|c|c|c|c|}
\hline \multicolumn{7}{|c|}{ Total Variance Explained } \\
\hline \multirow[t]{2}{*}{ Component } & \multicolumn{3}{|c|}{ Initial Eigenvalues } & \multicolumn{3}{|c|}{ Extraction Sums of Squared Loadings } \\
\hline & Total & $\%$ of Variance & Cumulative $\%$ & Total & $\%$ of Variance & Cumulative $\%$ \\
\hline COST & 2.130 & 19.363 & 19.363 & 2.130 & 19.363 & 19.363 \\
\hline SFT & 1.568 & 14.257 & 33.620 & 1.568 & 14.257 & 33.620 \\
\hline TECHN & 1.298 & 11.797 & 45.417 & 1.298 & 11.797 & 45.417 \\
\hline KNA & 1.175 & 10.684 & 56.101 & 1.175 & 10.684 & 56.101 \\
\hline EXP & 1.009 & 9.168 & 65.269 & 1.009 & 9.168 & 65.269 \\
\hline CULT & .900 & 8.184 & 73.453 & & & \\
\hline INST & .783 & 7.117 & 80.570 & & & \\
\hline ENV & .655 & 5.958 & 86.528 & & & \\
\hline LEG & .556 & 5.052 & 91.581 & & & \\
\hline SOC & .498 & 4.523 & 96.104 & & & \\
\hline POL & .429 & 3.896 & 100.000 & & & \\
\hline
\end{tabular}

Note: (COST: Implementation Cost, SFT: Staff Training, TECHN: Technological Factors, KNA: Knowledge and Awareness, EXP: Availability of Expertise, CULT: Cultural factors, INST: Institutional Commitment, ENV: Environmental Factor, LEG: Legislative factors, SOC: Sociological factors and POL: Political factors) 


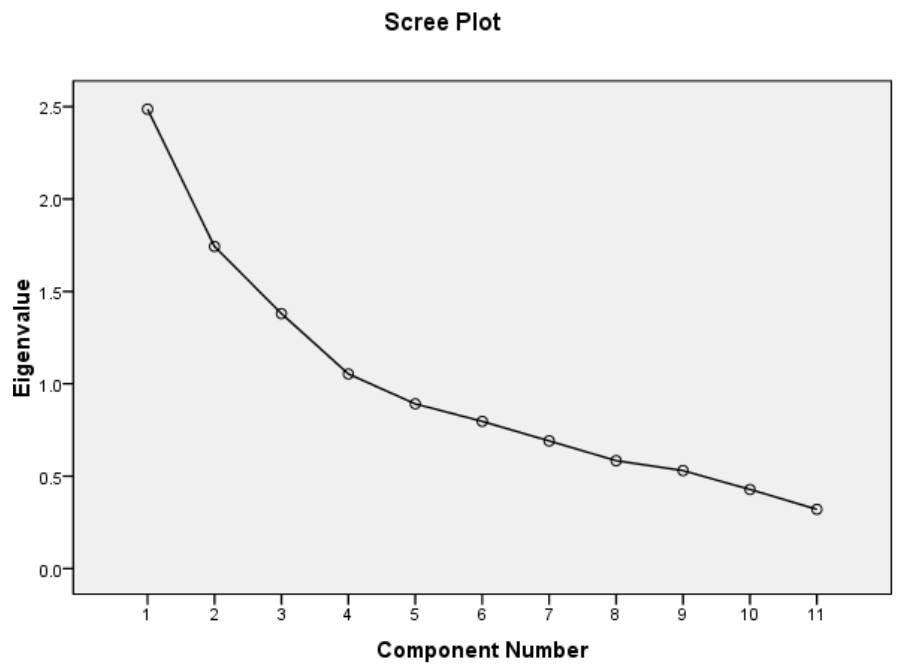

Figure 2. Factors affecting IPSAS adoption in Nigeria

Source: Field Survey, 2019

\subsection{Summary of Findings}

i. IPSAS adoption exerted positive and significant relationship with the quality of financial reports

ii. Significant and positive relationship was found between IPSAS adoption and credibility of financial statements

iii. Adoption of IPSAS enhances comparability of financial reports and international best practices among public sector organization in Nigeria.

iv. Implementation cost, staff training, technological factor, IPSAS knowledge and awareness and availability of expertise are crucial factors affecting IPSAS implementation in Nigeria.

\section{Conclusion and Recommendation}

\subsection{Conclusion}

This study evaluated the relationship between IPSAS adoption and financial reporting quality in South West, Nigeria. Specifically, it analysed the effect of IPSAS adoption on credibility and comparability of financial statements. Additionally; salient factors influencing IPSAS implementation were investigated. Primary data collected from one hundred and eighty accountants in South West Nigeria were analysed using tabulation, graphs, factor analysis, and Goodman and Kruskal's gamma statistics.

The empirical results indicated that IPSAS adoption exerted significant and positive relationships with financial reporting quality, credibility and comparability of financial statements. Decisively, discoveries from this study reflect that Implementation cost, staff training, technological factor, IPSAS knowledge and awareness and availability of expertise significantly affect IPSAS implementation. However, findings further revealed that IPSAS implementation is not significantly influenced by institutional commitment, cultural, sociological, legal, political and environmental factors. Based on these findings, the authors recommended that considerable amount of money should be set aside for full adoption and implementation of IPSAS in Nigeria

\subsection{Recommendation}

- IPSAS knowledge and awareness should be well integrated into the three tiers of the Nigerian government, and the public at large should be sensitized on the numerous benefits offered by IPSAS adoption.

- Government at all levels should recruit more accounting professionals and accounting personnel should be trained continually.

- Government should put measures in place to check compliance to IPSAS by public sector entities and violators should be punished accordingly to serve as deterrent to others. 
- Lastly, if Nigeria as a country is willing to partake in the numerous benefits offered by IPSAS adoption, then considerable amount of money should be set aside so that full accrual IPSASs would be adopted and implemented quickly.

\subsection{Limitation of the Study}

The study covered only South West Nigeria and may not be a representative of Nigeria as a whole. Further studies should examine IPSAS implementation in other regions of Nigeria and also in other developing countries like Kenya, Ghana, and Niger to mention but a few.

\section{References}

Acho, Y. (2014). The challenges of adopting IPSAS in Nigeria. Journal of Social Sciences and Public Policy, 6(2), 29-39.

Adamu, S. A., \& Ahmed, A. D. (2014). IPSAS andNigerian public sector: The challenges of first time adopters. International Journal of Social Sciences and Humanities Innovations, 2(1), 151-160.

Ademola, A. O., Adegoke, O. K., \& Oyeleye, O. A (2017). Impact of International Public Sector Accounting Standards (IPSAS) Adoption on Financial Accountability in Selected Local Governments of Oyo State Nigeria. Asian Journal of Economics, Business and Accounting, 3(2), 1-9. https://doi.org/10.9734/AJEBA/2017/33866

Ajayi, S. I. (2001). What Africa Needs to Do to Benefit from Globalization. Finance and Development, $38(4), 6-8$.

Alan, R., \& Susan, N. (2007). Globalization: Governmental Accounting and International Financial Reporting Standards. Socio-Economic Review, 5, 725-754. https://doi.org/10.1093/ser/mwm017

Anderson, J. (2009). Illusions of Accountability: Credit and Blame Sense Making in Public Administration. Administrative Theory \& Practice (M.E. Sharpe), 31(3), $322-339$. https://doi.org/10.2753/ATP1084-1806310302

Atu, O. E. O. K., Atu, O. G., \& Okoye, A. F. (2013). International Public Sector Accounting Standards (IPSAS): Challenges and Way Forward in Nigeria. Quarterly Journal of Associational of National Accountants of Nigeria, 21(1), 26-32.

Atuilik, W. A., Adafula, B., \& Asare, N. (2016). Transitioning to IPSAS in Africa: an analysis of the benefits and challenges. International Journal of Social Science and Economic Research, 1(6), 676- 691.

Babatunde, S. A. (2017). Implementing International Accounting Standards in Nigeria, Issues and challenges. International Journal of Business Economics and Law, 12(1), 2289-1552.

Ball, I., \& Pflugrath, G. (2012). Government Accounting: Making Enron looks good. World Economics Journal, $13(1), 1-15$.

Bellanca, S., \& Vandernoot, J. (2014). International public sector accounting standards (IPSAS) implementation in the European Union (EU) member states. Journal of Modern Accounting and Auditing, 3, 257-269.

Bergmann, A. (2012). The Influence of the Nature of Government Accounting and Reporting in Decision-Making: Evidence from Switzerland. Public Money \& Management, 32(1), 15-20. https://doi.org/10.1080/09540962.2012.643050

Brown, P. (2013). Some Observations on research on the benefits of nations adopting IFRS. The Japanese Accounting Review, 3, 1-19. https://doi.org/10.11640/tjar.3.2013.01

Chan, I. J. (2008). International public sector accounting standards: Conceptual and institutional issues. Reteived from http://jameslchan.com/papers/ChanCagSem5.pdf

Chan, J. L. (2005). 'Government Accounting Reforms in developing Countries': connecting MDG, PRS and IPSAS CIGAR. Retrieved October 2011, from http://www.feb.ugent.be/accoeco/PapersCigar2011/49

Christiaens, J., Vanhee, C., Rossi, F. M., \& Aversano, N. (2013, September). The Effect of IPSAS on Reforming Governmental Financial Reporting: An International Comparison. International Review of Administrative Sciences, 76, 537-554.

Corbetta, G., \& Salvato, C. (2004). Self-serving or self-actualizing? Models of man and agency costs in different types of family firms: A commentary on "Comparing the Agency Costs of Family and Non-family Firms: Conceptual Issues and Exploratory Evidence”. Entrepreneurship Theory and Practice, 28(4), 355-362. https://doi.org/10.1111/j.1540-6520.2004.00050.x 
Dana, L. P. (2001). Networks, internalization and policy. Small Business Economics, 16(2), 57-62. https://doi.org/10.1023/A:1011199116576

Freeman, R. E., Wick, A. C., \& Pamar, B. P. (2004). Stakeholder Theory and the corporate objective revisited. Organisation Science, 15(3), 364-369. https://doi.org/10.1287/orsc.1040.0066

Hamisi, K. S. (2012). The factors affecting the implementation of International Public Sector Accounting Standards in Kenya. MasterThesis, Science in Business Administration, The University of Nairobi.

IASB. (2008). Exposure draft on an improved conceptual framework for financial reporting: The objective of financial reporting andqualitative characteristics of decision-useful financial reportinginformation. London.

IASB. (2010). The Conceptual Framework for Financial Reporting. Retrieved from http://eifrs.iasb.org/eifrs/bnstandards/en/framework.pdf

Ijeoma, N. B. (2014). The impact of IPSAS on reliability, credibility and integrity of financial reporting in state government administration in Nigeria. International Journal of Technology Enhancements and Emerging Engineering Research, 2(3).

Ijeoma, N. B., \& Oghoghomeh. T. (2014). Adoption of international public sector accounting standards in Nigeria: Expectations, Benefits and Challenges. Journal of Investment and Management, 3(1), 21-29. https://doi.org/10.11648/j.jim.20140301.13

International Federation of Accountants (IFAC). (2017). Accrual Practices and Reform Expectations in the Caribbean. Public Sector Financial Accountability Survey Findings. Retrieved from http://www.ifac.org/publications

International Public Sector Accounting Standards Board (IPSASB). (2015). IPSASB FACTSHEET. Retrieved from http://www.Ifac.org

International Public Sector Accounting Standards Board. (2012). Conceptual Framework Exposure Draft 1. Conceptual Framework for General Purpose Financial Reporting by Public Sector Entities. New York, USA. Retrieved 22 October 2014, from www.ifac.org

Iyoha, F. O., \& Jimoh, J. (2011). Institutional Infrastructure and the Adoption of International Financial Reporting Standards (IFRS) in Nigeria.School of Doctoral Studies. European Union Journal, 3, 17-23. Retrieved from http://www.iiedu.eu/press/journals/sds/SDS_2011/BME_Article2.pdf

Kayode, O. F. (2014). Insight into Contemporary Public Sector Accounting and Finance. Larigraphics Printers, Eyamba, Jos.

Malahleha, R. (2012). Implications of adopting and implementing IPSAS. KPMG Services (Pty) Limited, a South African Company and a member firm of the KPMG network of independent member firms affiliated with KPMG International Cooperative (KPMG International), a Swiss Entity.

Mhaka, C. (2014). IPSAS, a guaranteed way of quality government financial reporting? A Comparative Analysis of the Existing Cash Accounting and IPSAS Based Accounting Reporting. International Journal of Financial Economics, 3(3), 134-141.

Mohammed, H., \& Allawi, A. (2014). Government Accounting System Reform and the Adoption of IPSAS in Iraq. Research Journal of Finance and Accounting.

Nkwagu, L. C., Uguru, L. C., \& Nkwede, F. E. (2016).Implications of International Public Sector Accounting Standards on Financial Accountability in the Nigerian Public. European Journal of Business, Economics and Accountancy, 6(6).

Oduware, U. (2012). IFRS Adoption in Nigeria and Optimizing the Gains of Global Investment Climate'Akintola Williams Deloitte (pp. 1-15).

Ofoegbu, G. N. (2014). New Public Management and Account Basis for Transparency and Accountability in the Nigerian Public Sector. Journal of Business and Management, 16(7), 104-113. https://doi.org/10.9790/487X-1673104113

Okoh, L., \& Ohwoyibo, O. (2010). Public accountability: Vehicle for Socio-economic development of Nigeria. International Journal of Investment and Finance, 3(2), 145-149.

Omolehinwa, E. O., \& Naiyeju, J. K. (2015). Government accounting in Nigeria: An IPSAS Approach. Lagos. Pumark Nigeria Limited. 
Opaniyi, R. O. (2016). The Effect of Adoption of International Public Sector Accounting Standards on Quality of Financial Reports in Public Sector in Kenya. European Scientific Journal, 12(28). https://doi.org/10.19044/esj.2016.v12n28p161

Ouda, H. A. (2004). Basic requirements model for successful implementation of accrual accounting in the public sector. Public Fund Digest, 4(1), 78-99.

Ozugbo, M. J. (2009). Financial Reporting for Good Governance in Public Sector Entities. In Nedaw, D (Ed.), Public Sector Accounting. Bahir Dar: Nakura Publications Ltd.

Prewitt, D. L. (2013, December 2-3). Training and education and the United States Convergence of International financial reporting standards (IFRS). Proceedings Kuala Lumpur International Business, Economics, and Law Conference (Vol. 1). Kuala Lumpur, Malaysia. Retrieved from http://klibel.com/wpcontent/uploads/2013/12/KLB3126-DPRWITT

Street, D. L. (2004). Convergence with IFRS in an expanding Europe: Progress and Obstacles identified by large Accounting Firms' Survey. Journal of International Accounting, Auditing and Taxation, 13, 89-119. https://doi.org/10.1016/j.intaccaudtax.2004.09.002

Tang, Q., Chen, H., \& Lin, Z. J. (2008). Financial Reporting Quality and Investor Protection: A Global investigation. Working paper. https://doi.org/10.2139/ssrn.1290910

Tickell, G. (2010). Cash to Accrual Accounting: One Nation's dilemma. International Business \&Economics Research Journal, 9(11), 71-78. https://doi.org/10.19030/iber.v9i11.32

Tikk, J. (2010). Accounting Changes in the Public Sector in Estonia. Business: Theory \& Practice, 11(1), 77-85. https://doi.org/10.3846/btp.2010.09

Udeh, F., \& Sopekan, S. (2015). Adoption of IPSAS and the quality of public sector financial reporting in Nigeria. Research Journal of Finance and Accounting, 6(20), 1-9.

UNCTAD (United Nations Conference on Trade and Development). (2008, May 27-29). Conference proceedings held in New York and Geneva. 